\title{
Virtuel Flaneuseasa New Consumer Identity: A Qualitative Research on Pinterest
}

\author{
Nilnur Tandaçgüneş, Istabul University, Turkey
}

\begin{abstract}
Cultural dimensions of products have virtually the same prominence as their functionality in network society. Nowadays, new consumer identities are also worthy being analyzed. The aim of this study is to focus on urbanization, a symbol of modernization, evolution of the observer, and explorer characters of themodern individual in initial periods into flâneurfrom the point of view consumption culture on the basis of postmodern reflections in social media. The evolution of flaneur, as an emphasis towards masculine nature of modern urban individual into flaenuse that is a victory won against sexism policy is a metaphor of cultural evolution. Therefore, the process of virtual flaneuse provides a considerable amount of descriptive material to have a sight of new consumer identity. This study aims to follow virtual flâneusewithin the context of Pinterest whose over $80 \%$ users consist of women. In this regard, this study employed semi structured interview method, one of qualitative research methods and also netnographic observation. Interviews with 13 women users from all Turkey and findings that were obtained via observations of researchers/participants in the field were analyzed. Thus, this provided opportunity to question existence and motivations of flaneur mentality as a consumer identity specific to virtual flaneuse. This study aims to make a theorical contribution to establishing a relationship between virtualflâneusephenemonen and consumption culture as there is no research regarding pinterest in communication field in Turkey.
\end{abstract}

Keywords: virtual flaneuse, consumer culture, social media, pinterest 


\section{Introduction}

The urbanization concept that was developed by modernity shaped in the light of political and social developments in $19^{\text {th }}$ century leads to social conditions that enableFlâneurtypology to be created and supported. Over time, flaneur, observer urban individual style that is familiar with city language emerges. Flâneurwith an identity that reflects his observations and experiences, modernity products, onto production phase differs from others due to critical notion he holds. The most significant themes that accompanyFlâneur, a symbol of rebellion rising from bourgeois class against penetration into, control and management of city over private life are "adventure" and "experience". Flaneur goes about places with a significant number of visual images and feeds especially from streets and passegeways that have emerged with modernity. Therefore, urbanization is inevitably followed by debate on place, space and time concepts.

Rapid technological advances in recent years seem to be a part of radical evolution between observer pattern and representation style. Emerging new images production technologies have also influenced functions of important social process. Herein, this situation causes observation and being observed subject to be a part of social, technological and economical instruments. It is consequently unavoidable to reread metaphors connecting image store today and heritage of past including flâneur as an important data.

It is highly siginificant to refer to "Arcades "by Walter Benjamin that was especially concerned with consumotion culture, modernity and city life in Paris, one of the most important metropolis in $19^{\text {th }}$ century and "A Lyric Poet in the Era of High Capitalism" (1938) by Charles Baudelaire in which he analyzed Benjamin's works as he first used flaneur metaphor in these works. The fact that Benjamin defined author that makes observations like an ethnologist and reflects this upon his production as a painter of modern era characterizes flaneur mentality. Indeed, the identity of flâneuris a "couch grass" that was born with avantgarde art towards the end of $19^{\text {th }}$ century and gained more power in $20^{\text {th }}$ century with advances in photograph, film and TV (Benjamin, 2004). Flaneurism described as a memory behind work of art itself evolved into a work of work (Wolff, 1994).

In the context of relations created among sight, subject, power, gaze of observer flâneur is an extensive material to read radical evolution of relationship between observing subject and 
representation style as a result of rapid technological advances in recent years. Therefore, what flâneurobserved and wrote is valuable as an ethnographic data.

Nowadays, flâneur/flâneuseexist within the systems of computer technology, consumption culture, control and surveillance. He goes about lateral communication platforms compatible with hybrid nature of reality and virtuality in metropol life style while he used to create new stories and works strolling on streets of modern city without aims and plans in $19^{\text {th }}$ century (McDowall, 2011:10-14). It is therefore necessary to recreate relations of flaneur with public sphere and network society (Featherstone, 1998:909-925). Because digital world creates Cyber Flâneur typology that observes other people's experiences by strolling in the parts of cyber city, listens to their dialogues, prefers occasional participation or only observation (Stevenson,2003:131\&Milburn:n.d.).

Today's flaneuse reveals herself in various fields like a consumer strolling in shopping malls, a stroller in public areas, internet user in cyber area or blogger. When how dominant appearance is on relationships of people with each other in advanced consumption society is analyzed, it is possible to say observing subject flaneur/flaneuse is necessary control barriers in alienated societies (Mitchell, 2000:3).Initially, modern flaneurhad a masculine identity. However establishment of shopping malls led to existence of female flaneur/flaneuse in society. It is possible to state that flaneuse was as active as male one in public areas and had her own cultural productions in consumption society towards the end of $19^{\text {th }}$ century. In network society, flaneuse is more significant because she provides a significant area to have an understanding of feminine aspect of her consumption habits in her consumption culture.

As a result of these reasons, this study aims to follow flâneuse who strolls without any plans and reflects her experiences onto visual culture, consumes while producing or vice versa on basis of pinterest whose over $80 \%$ users consist of women (mostly urban, university students or graduates, with high or middle level of income, between $25-44$ ) and which was completely designed for image store, share and production and has a social content.

\section{From Flâneurof Modernity towards Flâneur/Flâneuseof Postmodern Periods}

Imaginary meaning of $19^{\text {th }}$ century modernity includes an adventurous, innovative, temporary and flexible evolution belonging to a technic and secularist field and involving paradoxes. 
"Art" and "aesthetic" are most extensively effected areas in a negative way by this evolution because they are fed by daily life that is zeitgeist. Because "advertising, rheteoric of society, (replacing art and literature) not only interferes with missings and practice, but also deeply influences language, literature and social imagery in this highly organized social structure "(Lefebvre,2007:68). Therefore, daily life itself is organized with modernism. Flaneur whose biggest weapon is irony is the potential hero of modern culture (Frisby, 2001:27-52). Idleness of flaneur by Baudelaire represents a protestive behavior against the ones represented working class and industrial revolution. However, what would he do if he lived in the periods of department stores? Says Benjamin (Benjamin, 1989) in his comment implying early $20^{\text {th }}$ century. This study focuses on the essence of this question. When flaneur in postmodern times is analyzed, it is possible to say that flaneur is a figure who tries to survive in an attempt to objectifying city structures of late capitalism and keeping his objectivity while doing this. He avoids from routines of metropol life by trying to find mysterious and funny aspects of daily life. However, he achieves this by inclining to logic of meta which dazzles and excites him without being aware of it and socializing with it (McLaren, 1997:143-179). Therefore postmodern flâneurnot only hybridizes with public area but also still has an ethnographic value as he observes and records individual memory which is unique in the world under the influence of "heterogenous standardization". Because both classic flâneurand today's virtual flâneurmake up stories, follow tracks, creates, changes and produces new routes, new route maps while strolling on streets or cyber area without any purpose (McDowall,2011:78-126). While doing so, he feeds from spectacle of city life. However, new phenemona such as control, freedom from body, being an image, fracture, alienation in virtual flâneur leads to debates. As Bauman states, "space is the easiest place to fairly exist" (Bauman, 1998:32). Because, power infiltrates into space with symbolism. As area is used, it turns into a space.As Guy Debord points out; public area is an observation place of mainly advertising and consumption in the center of everything (Debord, 1994:2; Simmel, 1997:184). Today, space has lost its geographic value since it became virtual. Now it is very difficult to make a single and common definition for Postmodern Flâneur. He is now both a product of city and an author who experiences city. These experiences are obtained through industrialization and globalization. However, while today's flâneurhas more opportunities thanks to all internationalizing with the effect of industrialization and globalization, they are standardized (Ferguson, 1994:27). 
The paradox of Flâneuris that he both wants to isolate himself from population and desires to be a part of that population. He both likes rthyme, dynamism and liveliness of city and regrets time's flying. He both wants to see and observe everything and be invisible. Outside is a space of freedom, freedom of observing without being observed (Tseng, 2006: 225; Ivanchikova, 2007). Cartopgraphic view provided by system enables virtual flâneurto freely travel on streets, boulevards and visit any exotic and iconic corner in the world without living computer screen (Featherstone, 2006:922). This situation leads to a new debate regarding being visible of flâneurby changing his visibility status in the crowd and observing crowds from outside. Flâneurhas more difficulty being a productive, free and authentic individual in a consumption society where what we see encourages individuals to be a passive consumer. In fact, in our today's network society, analysis of how presentation of identified content to user influences meta culture leads to debate regarding production of aesthetic practices focusing on interactivity, occupation of private life, attraction, creativity and characteristics of individuality again and again. In postmodern culture, standardization of images created and becoming widespread in social memory where time converts into space, body into electronic causes flâneurwho misses pastto have a nostalgia deficiency. Because flaneur needs to be an individual when all rituals, routines, beliefs and values are common (Taylor \& Smith, 2000:279-294; Ghasemi \& Ghafoori, 2010:74-88). For example, improvised street culture that makes street, walls, public areas production object continues to live in flâneur's artistic identity.

\section{VirtualFlâneuse as a New Consumer Identity}

The main problem about existence of Flâneusethat was first discussed against masculine identity of flâneurin the $19^{\text {th }}$ centurylies in the fact that flâneur himself does not have freedom of being invisible whil seeing, following everybody (Russell, 2000: 1-15). Because woman is object of man's gaze.

Women had neither the chance of not drawing attention while going about public place nor the freedom of flâneur. For the very reason, Janet Wolff asserts in her article called "The Invisible Flaneuse" (Wolff, 1985; Wilson,1992:90-110) that modernity literature defines men's experience. Business, politics and city life are the places where women are excluded and invisible. Therefore, man is flaneur who spends time in café, strolls on the streets, goes to theatre, freely goes about public places, and in other words reveals experiences of modern 
life. The main problem of modernity literature therefore lies in the fact that it ignores women's lives and grows poor (Özsoy, 2012:303-320).

According to Baudelarie, women are subjects of gaze or objects of botanics as a plant in accordance with metaphor by Benjamin (Wolff, 1985: 41). As AnkeGleber suggests, idleness has become not only a privilege for bourgeois, educated white middle class but only a luxury for man society since $19^{\text {th }}$ century. Because while man contemporaries explore city, women are in struggle for obtaining opportunities that are reserved for man (Gleber, 1999: 172).

While shifting from passages to big stores is beginning of end for flâneur, achieving to freely go about and see public places for women, namely existence of Flâneuse in history date back to development of shopping malls (Tseng, 2006: 236). Both breakdown of modernist flâneur from the point of cosmopolitan view of metropol life and simultaneous acceptance of existence of women without any interior pressure enable flâneuseto be regarded as "cultural subject" (Freidberg, 1993:15-41).

In today's network society, existence of flâneuse has a different significance because her observations about daily life provide a great deal of data for cultural studies of production and consumption habits in a feminine way (Frisby, 1985; Gleber, 1997: 78-79). Everyday life was transfigured by "social multipication of images". In this new visual culture, mobilized and virtual view of flaneuse is shaped by fashion, advertisements, experiences and memories formed in the center of photograph (Freidberg, 1993:15-41).

\section{Pinterest as Virtual Data Space}

In this part we studied on, social network pinterestas establisment in 2010, according to differntresearchs statistic info and netrografic dates that we assembled.Pinterest is presented in a way unlike other social media platforms and provides users with a different social media experience. The site works as a virtual scrapbook on which users (called pinners) save images into a virtual folder called a pin board. Users pin images, along with short notes about the image, onto pin boards that are generally based on a particular theme that matches the user's interest. Users can also simply like another user's image to indicate their interest or if they do not have a pin board they want to pin the image to. Content is originally pinned from a website other than Pinterest. In creating their own Pinterest page users can either pin original content from another website or repin other users' content onto their own boards. The image 
contains a link that takes viewers back to the original website. Furthermore, users can search for pins based on their personal interest (Zeckman, 2014).As of January 2014, Pinterest that had reached more than 51 million monthly unique visitors worldwide, is available in more than 30 different languages and can be accessed through three different platforms: Web, Android, and iOS. Pinterest does not provide a public API for data collection for researchers.

The most blanket emprical research about pinterest that was according to their facebook accounts show us that 1.61 million (\%87.15) women and 130,945 thousand (\%7.04) was men. Users dispersion frequencely of occurancein countries is shaped like U.S.A., Canada, U.K., Brazil, India, and Europe. And also in Africa, Russia ve China users are at least populous. Otherwise Majority of users are living in metropolis (Mittal vd., 2013). As we focused on users ocuppations profile, in order of; Designer, Interior Designer, Blogger, Architect, architecture student, artist, freelancer and not mentioned are constitute (\%25) of all users. And their topics in pinboards are arrange like, "my style", "favorite recipe", "food \& drink", "craft ideas", "for the home", "wedding ideas", "books worth for reading", "Favorite Places", “Christmas".Especially 25-27 ages users and 35-44 ages users are occured. \%28 percent of these has high income and general of them middle high incomes. $\% 20$ percent of useres has loaded their own pin anda \%80 of them repin the other users. Users general obliquity is on following boards that they like not the other users (Spitznagel, 2013).

Pinterest users are not expected to be a passive consumer of the content posted by his or her followers, and Pinterest offers several ways to interact with the content shared by other people (Zarrovd. 2013:650-658). Pinterest, a site that allows users to link to, sort, and save images, videos, and other media content. According to their homepage, "Pinterest is a place to discover ideas (Linvillvd., 2015:287-300). Also users see pinterest as a better use of time compared to other forms of entertainment, such as watching television (Linder,2014).Pinterest is widely used by nonprofit organizations, educational institutions, individuals and the private sector to promote brands, causes, issues and stories that are important to them. Also with its visual images that are easily shared, Pinterest is a very useful tool for marketing (Lupton,2012). Pinners may repeatedly revisit their boards in search of inspiration. Pinterest offers numerous benefits to businesses, with the simple format allowing companies to establish themselves in a more familiar and personalised manner (Linvillvd., 2015). 
As we looked on a survey that was studied on Pintrest Users consumer motivation standart users pins and pinboards are classified on five main topics (Mull; Lee, 2014: 192-200). Accordingly, the users consumer motivations are; 'fashion', 'creative projects', 'entertainment', 'virtual exploration', and 'organization'. Also if we look the basic using motivations of the users; Individuals use digital found objects as creative resources to develop ideas for shaping their lives. They assemble information into new contexts, forming and sharing ideas with practical and emotional value. Pins are flexible. Everydayideators appropriate information, pinning and repinning with particular purposes. Purposes encountered include: motivation, planning, ideation, goal- setting, to increase expertise, to comfort, to entertain, and to self-actualize. According in an other survey focused on pintrest responses to sales.Buna göre Pinterest is an especially popular driver of in-store sales: $21 \%$ of the Pinterest users they surveyed said that they bought an item in-store after pinning, repinning, or liking it, and 36\% of users under 35 said they had done so (Sevitt,Samuel 2013). Morover if we looked on researchs that focused on usersdemografic characteristic, young univercity students are comman. And their motivation on pintrest is about cerative mind, share experiance and society relationships. The power of Pinterest will require marketers to carefully examine the brand's core proposition, produce historically and contextually rich, temporally ordered, and tastefully curated photographic albums to aid in their target audience's authenticity and seeking experiences(Sashittalvd., 2015).

\section{Methodology}

This study employed two types of qualitative data collection instruments. Firstly, data was collected through netnographic method as a participant researcher and then analyzed. Later 13 users were used by means of snowball sampling and semi-structured in-depth interview was employed to examine how much virtual flaneuse identity overlaps with pinterest users in terms of consumer culture. Data was assessed through thematic analysis. This technique was employed to deeply examine meanings rising from experiences of participants. It was therefore possible to access perspectives, subjective experiences, feelings, values and perception of participants as well as psycho- social, cultural and physical characteristics of environment where study was carried out. Theoretical information was employed to create interview questions and assess answers. 


\section{Findings}

Users were reluctant to share their nicknames because they did not want information on their pinboards to be known. Therefore participants were coded as "K1" with a meaning of user. Main questions and probe questions were called "1", "1a", “1b" etc. Remarks by participants were quoted as "K1/1A" in the phase of finding assessment.

When answers to question asked to understand motivation for pinterest usage were analyzed, it was observed that they describe pinterest as a new platform where they can easily find images they like and archive them. Some started to use pinterest for project assignment, some started because of curiosity aftet they heard it at a conference. There are also people who want to develop their hobbies and make a image collection. “ $\underline{\mathbf{K} 4 / \mathbf{1 B}}$... I really needed such service. I think many people from especially art and design fields also need this. Because it is really important to have such platform like this to categorize your own visual taste and save content which includes subjects you get inspiration". Likewise, the statement that "K1/1B archiving, aesthetic, art and visuality are words that describe me..... it is very great not to have to communicate with anyone, you do not have to be in touch with people you have just pinned, it is superb to invisibly save what you see! 'refers to flâneur's characteristics free from gestural and verbal communication defined by Simmel. This point of view observes commerce and advertisement produced by controlled society unlike panoptic view of Foucault(Foucault, 2004). As Bauman suggests, success of Flaneur's art lies in the fact that he manages to observe without being visible (Tester, 1994:141). At this point, being invisible create the most free and unique aspect of Flâneur's observation.

As Buck-Morss suggests,'Intellectual rambler “flaneur evolved into a new employed salaried type who produces literature and advertisements with the aim of information, entertainment and persuasion. In addition, these genres are so intermingled that they are diffult to be distinguished from each other. Because flâneur, becomes a storyteller of real conditions of city life and thus prevents his followers from getting bored with reality (Buck-Morss, 1989:307). Therefore ideologies circulate with fashion and advertisement. In fact, education and profession information of users who produce and create have all post graduate education or are university students. Their professions range from architect, artist, communication student, digital designer, interior architect, instructor, to marketing expert and housewife. 
When answers to question about usage frequency asked to understand relationship with pinterest were analyzed, it was observed that they use it as a leisure time activity and source of inspiration as can be seen in statements such as " $\underline{\mathbf{K 1 / 1 C}}$ I think I use it more often when I am home and do not go out than when I am at work ....... holidays even though it is not fixed......K10/1C how often I use it depends on whether I am curios about something those days....

Users' pinboards primarily consists of decoration, street art, cinema, painting, sculpture, photograph, architecture, antique, handicraft, tattoo, fashion, digital arts, sayings, image share, science technique, child care, journey, food, (do it yourself) and vocational information. They choose one of them depending on their "curiosity "and "interest fields". "K10/5A if I said I choose it depending on changes in my life and my psychological status, would it be too vague? For example if I get too bored, I will look at DIY. Finding new opinions and things I can easily produce relax me. .....however, while looking at a pin, you go to another one and I can find myself in an irreleavant place. Sometimes I can randomly go to a pin after looking all subjects. Therefore, they freely ramble depending on changing moods.

Impressions of flaneur in the center of relationship among customs, text, phenemonan and people are reflections of relstionshipbetween surrounding and appearance, experience and memory, perception and accumulation. As Caygill suggests, "Flâneurequips his mind with current experience. This changes city experience and makes current moment forever" (Caygill,1998:68). Just like the attempt to seize soul of time as can be seen in answers to question about which themes they use for cyber surfs such as “ $\mathbf{K 6 / 2}$ I have pinboards where there are photos of Istanbul, words of wisdom, fragments of animation movies, things I like, decorative products, scenery from worldi cities, individual photos, scenes of video clip of lana del rey's two songs I like and their lyrics, light \& illuminations, cats, products including patterns of constellation, space, illustrations \& creative things, albums consisting of photos from Greece, Italy and Spain, street art photos, nebulas, photos from all Turkey taken by me or "K1/2A I am already into archiving and collecting, I have had a diary since primary school.... Pinterest is an inspiring pkace for me "“ looking them again. So, I have a pinboard including photos of places I want to be. 
The more flaneur that is going away from romantic hero by Benjamin loses connection with city, the more he loses artistic power and creativity. Flâneur who finds himself in a community controlled by mass media forgets to ask under whose influence he is. Therefore, alienation is now just conceptual (McDowall, 2011:11). The main points they have in common are that they travel without plans and finger the pulse of space with observations. In this direction, how much they reflect their individuality building onto images on pinterest was examined. When answers to this question were analyzed, it was observed that they mainly focus on contents related to journey/travel, art, profession and dreams. Because individuals think that themes they are interested in reflect their intellectual characteristics and/ or who they want to be. " $\underline{\mathbf{K} 1 / 2 \mathrm{~B}}$ in fact all of them because all of them creates me, namely pinterest is a visual map of my interest fields that creates me, artistic pinboards such as film, sculpture, painting, photograph, sculpture, things I dream of but I haven't achieved yet. $\underline{\mathbf{K} 2 / \mathbf{2 B}}$

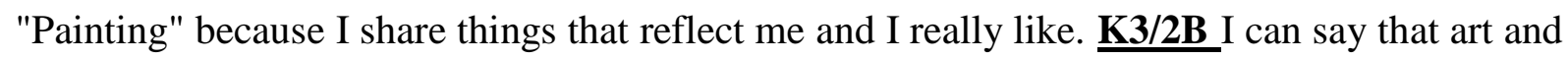
graphic pinboards reflect my visual taste. My TV and advertisement pinboards reflect my perspective.... From these, one can understand my sense of humour. K4/2B I think each pinboard defines my different aspect, for example pinboards with artistic content reflects my visual taste and art I want to priduce while the ones with fashion content reflect my dressing

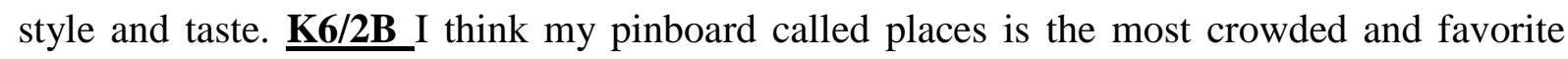
one.... I want to travel all around the world, I achieve my dream thanks to this pinboard $\odot \underline{\mathbf{K} 7 /}$ 2B I am interested in jewelry pinboard these days. Because it inspires me to make my own

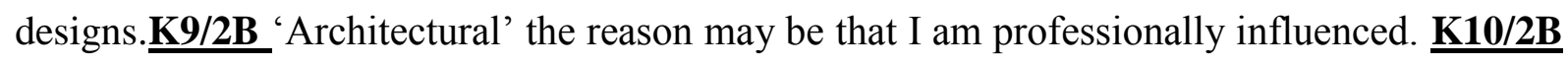
tattoos I like $;$ it is completely related to me, my body. So it really describes me ".Simmel approves of visual common sense in city life in his studies about modernity and city life. Flâneur has neither plans about his behsaviors nor strategies. On the contrary, what he encounters on his way is material for his art. Why he is similar to an "etnograph" results from his competence in unmediated observation (Savage\&Warde, 1993:115). Indeed, Common answers to to question asked to have an understanding of whether pinterest users move with plans and strategies center upon that they spontaneously surf and prefer going from one image to another when they see an inspiring thingit is possible to summarize the common different

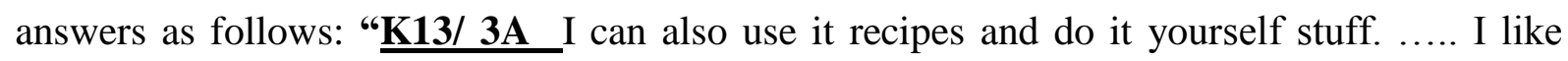
pinterest because it is free from commercial concern and is suitable for bohemian soul. .

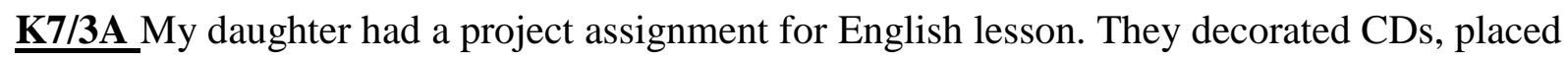
them properly and created a board. Then, I said I am so lucky to have such service. 
When answers to question asked to understand differences between strolling on streets and socializing in real life and and rambling on cyber space were analyzed, statements by some user such as $\underline{\mathbf{K 1 / 3 B}}$. it is a great dream to collect images of clothes that amaze me and would not look good on me even if I bought them or it is a great pleasure to like something on pinterest and look for it in stores.... K11/3B pinterest is kinda place where I like being alone.... Maybe sitting in a café in a city you have never been before, sipping your wine and watching it.... I even like the feeling that you don't have to communicate with people when you pin their shares or follow their pinboards. ... pinterest is very amazing because it like

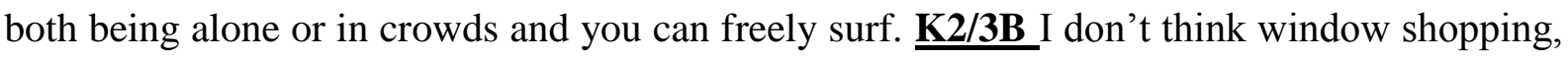
going to shopping malls, leafing through the magazine aren't really different from surfing on pinterest. We surf on pinboards, other accounts to find what we look for. $\underline{\mathbf{K} 3 / \mathbf{3 B}} \ldots$ it is certainly easier than going from one strore to another. Especially to have an idea. There are

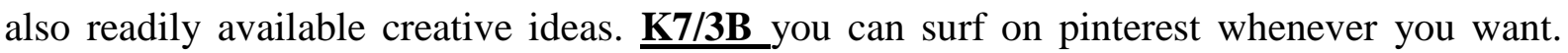
You are not addicte to anyone. It is a platform where you can meet people without making any phone calls/ appointments." show a similar mood to meaning of which flâneur assigned to idleness such as freely and lonely observing, getting inspiration, experiencing. Flaneur is aware of the need of being stranger to authenticity and he also knows he can have a better observation with adaption to his surrounding. Flâneurhas more difficulty being a productive, free and authentic individual in a consumption society where what we see encourages individuals to be a passive consumer (Tseng, 2006: 225). In this sense, users are aware of the fact that any kinds of "experience type" are intermingled with consumption culture. They express themselves by saying “ $\mathbf{K 4 / 3 B}$ pinterest is a platform completely based on visual content. So experience part of a product or service is a little bit missing, I think. $\underline{\mathbf{K 5 / 3 B}}$ nothing can be give as much pleasure as my friend who say good morning and I drink coffee with, clothes I touch and buy and a book whose pages I smell... so even though it entertains me, I give up my phone with pangs of conscience after using it half an hour.

When they were asked to compare efficieny of pinterest with other networks in terms of accessing to new information of their interest fields or taking up new pursuits, they expressed

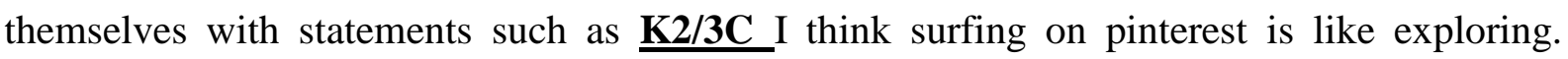
Because when we look at any images, we can find so many similar images. Neither a social network nor a person regardless of his high level information can provide this opportunity, I think. $\underline{\mathbf{K 4 / 3 C}}$.... You can encounter an idea or job you have never seen in your life when you 
make pinterest feed popular or everything. K5/3C ... when I open a blank space like google, nothing comes to my mind to write. But pinterest itself provides this. $\mathbf{K 6 / 3 C ~ . . . . f o r ~ e x a m p l e ~}$ Greece is a country I most would like to visit. I learnt city names, natural beauties in Greece by pinning photos. Now, I learn most places by heart.

When they were asked about how they benefited from pinterest in terms of learning new things or "sharing intellectual things ", they mainly gave positive answers. The feeling they

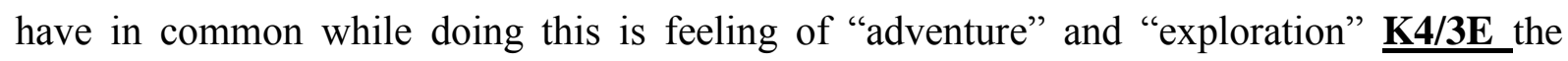
subject where I most learn is DIY. ... I don't consciously browse to access to an information..... I find them by chance and sometimes I encounter with really interesting and inspiring projects. $\underline{\mathbf{K 6} / \mathbf{3 E}}$ I generally surf for new places, cities. What each city has etc. $\underline{\text { FK9/3E }}$ architectural and aesthetical point of view about different subjects from different parts of the world. K10/3E I have a word list about my favourite subject. While surfiong on them, I find new things". When they were asked to inform us about their usage habits of a leisure time activity and socializing, they stated that they do not use pinterest to chat with someone on some one and don't have such aims. This situation is parallel to flaneur's desire of being alone while he is rambling. When they were asked to tell sense of satisfaction as a result of image archiving that reflects their likes, the answer mainly included "adventure", "experience" and "nostalgia" accompanying romantic heroism of flaneur. "K1/4B it is very nostalgic and exciting because it is like looking at old magazines and photo albums over and over. When I get bored or sad, I like looking at things that made me smile, inspired me before over and over". $\underline{\mathbf{K 3} / \mathbf{4 B}}$ archiving images I like really makes me happy.... It is like a column you can store images you like and even share them with your friends. This is kinda' museum of innocence ${ }^{1}$ In addition, with her pinboards, flaneuse virtually reconstructs her own indivuality by means of ideal individuality construction she created from images. "K13/4B pinterest is a platform that has defined me best so far. Because I give the most clues about myself here and I feel free. $\underline{\mathbf{K 3} / \mathbf{4 B}}$ I think I like visually expressing myself.

Museum of innocence: it is the name of an ethnographic museum that Turkish novelist OrhanPamuk with Nobel Prize bought after his novel with the same name and has similar traces of his personal history and consists of nostalgic things collected in panaroma of Istanbul memories. "K2/4B ... the feeling it gives me most is feeling of "reexploring yourself" it seems to me all describe me when I put together all works I filed and compile them. It feels 
as if they form my past, dreams, mind and heart. $\underline{\mathbf{K 4} / \mathbf{4 B}}$.... I find being a collector in any fields similar to being a pinterest user. It is a very satisfying process to save images and have a library whose pinboards reflect your style and taste day by day. $\underline{\mathbf{K} \mathbf{5} / \mathbf{4 B}}$ it is like a memory box..... think about a box you put all gifts for you, some notes, things you bought from somewhere. When you open it one year later, you are surprised about what you see because maybe you have forgotten about them $\odot \underline{\mathbf{K 1 1} / \mathbf{4 B}}$... sometimes a picture makes you happy and helps you forget your difficult times. My pinboard that inclused my old pictures relaxes and makes me happy in a similar way. “

When they were asked to explain what effects their choices in making new pins or following pinboards in order to have a sight of daily life, personal production and consumption, they pointed out that they are selective and conscious and very careful about whether pins are professionally prepared in technical way, include true and detailed information about image, provide inspiration. "K1/ 5A the fact that it is inspiring, has a lot of options and actively makes pins influences me. $\underline{\mathbf{K 2} / \mathbf{5 A}}$ there are qualified and right images on pinterest and such technical elements influence my choices. ..... it is necessary to have less known images as well as well known images. $\underline{\mathbf{K 5 / 5 A}}$ I generally seek for artictic view and meaning. It has to give me a feeling or an information". Today's flâneur creates contents about problems in society he lives such as gender, ethnicity, war and environmental politics and shares them. This makes him not only a participant but also an active actor in discourse production (Jan, 2002). Although pinterest is used in accordance with this aim, users do not use and especially prefer it with sense of social responsibility. We observe that virtual flaneuse like user saying thatKl1/ 5B I don't bring social responsibility projects I undertake on different platforms onto pinterest.... I think I like pinterest because it doesn't affect you as long as you don't want. "prefers to have "apolitic attitude" and have especially do it yourself stuf, journey observations and artirstic preferences.

On the other hand, answers to the questions about whether they develop susceptibility against sharing image that includes brand name or product/ service information on pinterest indicate that users "develop susceptibility "in this subject. In other words, today's flaneuseis not only an object of consumption but also exists by maintaining his "critical perspective" in this field he observes and shares his observations. . "K2/5CI try not to do so. In other social networks or even e-mails, you can't avoid from advertisements, product/service information. I want to 
benefit from this as much as I can while there is still a chance to avoid from all these on pinterest. K3/ 5CYes, I pay attention. This is because of the fact that I think that such marketing-oriented contents disrupt the inherent aesthetics of Pinterest. They lead to an excessive amount of visual pollution and meaningless content. Or there are answers emphasizing the critical notion of flaneur. "K1/5C.Yes, actually I try to pay attention. However, there are things that I ignore particularly in subjects concerning fashion since I do not want to spend time sorting out the information. Also, the fact that young designers and artists use this platform in order to promote themselves does not bother me. If we consider them as the continuation of small boutique businesses instead of the shopping malls of the big multinational companies, we can even say that it is nice. "K5/5C. Such profit-oriented brand information appears to be fake. I cannot say that I do not follow them as a conscious reaction, I just avoid of them as a reflex." In addition to the users giving the abovementioned answers, there are others saying the following about this situation with a cynic attitude: "K8/5C. I do not feel uncomfortable about brand sharing. Instead, I enjoy knowing what belongs to which brand."

When the answers of the questions aiming to figure out what they think about sharing saleoriented products that they produce, instructive visuals or artistic productions are considered, people usually find Pinterest as the most appropriate platform for the sharing of such elements. On the other hand, it is seen that they are still hesitant about the sharing of amateur videos and photos except for those personally engaging in art. However, there are also such answers: "K4/5D I am not sharing yet, but I am planning to share my artistic works in the future. It is a great opportunity for new artists attempting to make a name for them. $\underline{\text { K6/5D }}$ Yes, I share my photos. I want to have them spread to a wider audience.”

\section{Conclusion}

In the light of the information obtained in the research, it can be stated that virtual flaneuses that succeed in observing without being seen and reflect the observations on their own productions use Pinterest mainly for getting inspired and collecting moments of pleasure by strolling among visual images. Besides, they create their own personal libraries by regarding the visual richness of the space as a unique data/strolling area. The fact that pins and pinboards are collected mainly under the themes of decoration, street art, painting, sculpture, photograph, architecture, design, handcraft, tattoo, fashion, digital arts, wise sayings, visual 
memory sharing, travelling, food, DIY and professional information shows the similarity of "tastes" and "areas of interest". They also consider Pinterest as a leisure where they can lounge around freely via the instant pins they send according to their moods. In this selffeeding cultural habitat where they create the information of the space with their own experiences and memories, the aim is to seize the zeitgeist. Thus, they restructure themselves in a virtual environment through the ideal identities they create with visual images.

When the sensitivities they develop as consumers are examined, it can be said that they display an apolitical attitude in this social platform open to the posts of business entities. Considering the reflections of strolling on the consumption habits, they express that images related to fashion and decoration provide inspiration for their shopping activities. Besides, it is seen that they develop sensitivity against the sharing of images containing information about prices/brands since they use this platform primarily for do it yourself (DIY) works (particularly food, art, fashion and design) based on the sharing of personal and voluntary experiences. Also, they support the self-promotions of young and new artists or small boutique firms. In this way, they target to generate an alternative perspective to the capitalist consumption culture. In other words, virtual flaneuses of Pinterest make their presence felt not only with their position as the object of consumption but also by preserving their "critical perspective" in this platform where they observe and share their observations. The fact that they pay attention to such issues as whether pins/pinboards are inspiring, whether they are prepared in a professional manner in technical terms and whether they contain correct information about the image while they send pins or follow pinboards supports this attitude. They do not use this platform for socialization since flaneurship is a solo adventure for them. The themes of "adventure", "collecting", "experience" and "nostalgia" accompanying the romantic hero emphasis of the flaneur determine their habits of archiving. They make use of Pinterest for the sharing of intellectual knowledge and the shared sentiment they have is the feeling of "adventure" and "discovery" accompanying the excitement caused by spontaneity. All these sentiments and behaviors demonstrate a mood that is highly similar to the meaning ascribed by the flaneur to the flaneurship which includes observing freely and alone, getting inspiration, experiencing and gaining impression etc. While they take the pulse of the space through unplanned and unscheduled strolling, they focus on contents about travelling/trip, art, profession and dreams etc. Furthermore, while they attempt to be visible through images, they 
show ultimate attention to ensuring that the themes which they are interested in reflect their intellectual identities.

When we look at the assessment of the research, observations and experiences of the virtual flaneur/flaneuse have guided us in today's network society by taking the ethnographic value of the flaneurship as reference in the urban culture where the consumption culture developing in parallel with the modernism has grown. Therefore, the motivation of the flaneuse, feminine version of postmodern flaneur, was chased up in the specific case of Pinterest. The fact that there is no study in the literature hunting for the virtual flaneuse in the case of Pinterest which has become the third biggest social networking site of the world and that no study has been conducted on Pinterest in Turkey so far serves as the indicator of the contribution of this descriptive research to the field. We hope that this research will shed light on the future research to be conducted particularly on Pinterest and for assessing the motivation of the new consumers. 


\section{References}

Bauman, Z. (1998). Globalization, The Human Consequences, NY: Colombia University Press

Benjamin, W. (1989).Charles Baudelaire: A Lyric Poet in The Era of High Capitalism, (H.Zohn: Ed), London:Verso

Benjamin, W. (2004).Pasajlar, (Trans. Ahmet Cemal), İstanbul:YKY

Buck- Morss, S. (1989). The Dialectic of Seeing: Walter Benjamin and the Arcades Project, Cambridge Press: Cambridge

Buck-Morss, S. (1986). The Flâneur, TheSandwichman and the Whore: The Politics of Loitering.New German Critique, 9(1), p. 99-141.Retrieved from http://links.jstor.org/sici?sici=0094033X\%28198623\%290\%3A39\%3C99\%3ATFTSAT\%3E2.0.CO\%3B2-4

Debord, G. (1994).The Society of the Spectacle, (Trans. Donald Nicholson-Smith), New York : Zone.

Featherstone, M. (1998).The Flâneur the City and Virtual Public Life,Urban Studies, 35(5-6), p.909-925.Retrieved from http://usj.sagepub.com/content/35/5-6/909.extract

Featherstone, M. (2006).Archive, Theory, Culture \& Society, 23(11), 591-596.Retrieved fromhttp://tcs.sagepub.com.

Ferguson, P. P. (1994). The Flâneur on and off the Streets of Paris(Ed. K. Tester), The Flâneur (pp.22-42), London: Routledge.

Foucault, M. (2004).FelsefeSahnesi: SeçmeYazılar V, Trans:IşıkErgüden, İstanbul: Ayrıntı Freidberg, A. (1993). Window Shopping: Cinema and Postmodern, California: University of California Press.

Frisby, D. (2001). The Flâneur in social Thoery, (Ed. D. Frisby)City Scapes of Modernity, (pp.27-52) Cambridge: Blackwell.

Frisby, D. (1985). Fragments of Modernity; Theories of Modernity in the Work of Simmel, Kracauer, Benjamin, Cambridge and Oxford: Polity Press and Basil Blackwell.

Ghasemi, P.; Masoud, G. (2010).Holden in Search of Identity: Recreating the Picture of the Flâneur, English Studies, Routledge, 91(1), p.74-88. Retrieved fromhttp://dx.doi.org/10.1080/00138380903355098

Gleber, A. (1997). Women on the Screens and Streets of Modernity: In Search of the Female Flâneur, in Dudley Andrew (ed.) The Image in Dispute: Art and Cinema in the Age of Photography, (pp. 55-86), Austin: University of Texas Press,. 
Ivanchikova, A. (2007). “ Sidewalks of Desire: Paradoxes of the Postmodern Flâneur in Contemporary Queer fiction. Comperative Literature Dpt. Doctor of Philosophy, Buffalo State University. New York. Retrieved fromhttp:/gradworks.umi.com/32/91/3291578.html

Jan, S. (2002). "The Rebirth of the Postmodern Flâneur: Notes on the Postmodern Landscape of Francesca Lia Blocks Weetzie Bat" Marvels and Tales, Wayne State University Press, 16(2).Retrieved from http://digitalcommons.wayne.edu./marvels/vol16/iss2/4

Lefebvre, H. (2007). Modern Dünyada Gündelik Hayat, (Trans: IşınGürbüz), İstanbul: Metis yayınları

Linvill, D. ; Rowlett, T. J. \&Kolind, M. (2015). Academic Pinstitution: Higher Education's Use Of PinterestFor Relationship Marketing. Journal Of Relationship Marketing. p.287-300. Retrieved from http://www.tandfonline.com/loi/wjrm20.

Linder, R.; Snodgrass, C. \&Kerne, A. ( 2014 ). Everyday Ideation: All of My Ideas Are On Pinterest.Retrieved from http://ecologylab.cse.tamu.edu/research/ publications/everyday_ideation_pinterest.pdf

Lupton, D. (2012).More than just a pretty picture? How sociologists (and other social scientists) can use Pinterest. Retrieved from http://blogs.lse.ac.uk/impactofsocialsciences /2012/06/22/ pretty-picture-pinterestsocial-science/

Spitznagel, E. (2013), It's Pinterest—For Dudes!, Bloomberg Businessweek (April 29-May 5), p.63-65

Mclaren, P. (1997). “The Ethnographer as Postmodern Flâneur: Critical Reflexivity and Posthybridity as Narrative Engagement", Representation and the Text Re-framing the Narrative Voice, (Ed. G. William ; T. Yvonna\& S. Lincoln), p.143-179, NY: State University of New York Press. Retrieved from http://www. pressbook.google.com

Milburn, K. (n.d.). Following the Flâneur: a methodological and textual critique.Retrieved from http://www.nottingham.ac.uk/cas/documents/landscapes/kevinmilburnfinal.pdf

Mitchell, W.J. (2000). E-topia: Urban life jim-but not as we know it, Cambridge: MIT Press Mittal, S.; Gupta, N.; Dewan, P. \&Kumaraguru, P. (2013).The Pin-Bang Theory: Discovering The Pinterest World.Retrieved from http://arxiv.org/pdf/1307.4952.pdf;

Mull, I.R. ; Le, S. E. (2014). "PIN" pointing the motivational dimensions behind Pinterest, Journal of Computers in Human Behavior, 33(3), pp.192-200. Retrieved fromwww.elsevier.com/locate/comphumbeh 
Russell, C. (2000). Parallax Historiography: The Flâneuse as Cyberfeminist, Concordia University. Retrieved from Canadahttp://www.nottingham.ac.uk/ scope/documents/2000/july-2000/russell.pdfj.

Sashittal, H.; Jassawalla, A. (2015).Why Do College Students Use Pinterest? A Model and Implications for Scholars and Marketers.Journal of Interactive Advertising, 15(1), pp. 54-66. Retrieved from http://www.tandfonline.com/loi/ujia20.

Savage, M. ;Warde, A. (1993).Urban Sociology, Capitalism and Modernity.London: MacMillan Press

Sevitt, D.;Samuel,A. (2013).HowPinterest Puts People in Stores. Harvard Business Review Press.Retrieved from http:// visioncritical.com/pinterest.

Simmel, G. (1997). The Metropolis and Mental Life, (Ed. D. Frisby; M. Featherstone) in Simmel on Culture, (pp.174-186). London:Sage.

Steveson, D. (2003). Cities and Urban Cultures. Maidenhead/England: Open University Press.Retrieved from http://openup.co.uk

Taylor, M. ; Matthews, H. ; Smith, B. P. (2000). Unacceptable Flâneur, The Shopping Mall as a Teenage Hangout.Norwegian Centre for Child Reseach.p.279-294. Retrieved from http://chd.sagepub.com/content/7/3/279.full.pdf+html

Tester, K. (1994).The Flâneur, London: Routledge, Retrieved from http://books.google.com.tr/books?id=OGPMUcnNvQC $\&$ printsec $=$ frontcover $\& \mathrm{hl}=\mathrm{tr} \# \mathrm{v}=$ onepage $\& \mathrm{q} \& \mathrm{f}=$ false

Tseng, C. F. (2006). The Flâneur, the Flâneuse, and the Hostess: Virginia Wolff's (Un)Domesticating Flanerie in Mrs. Dalloway, Concentric: Literary and Cultural Studies, 32(1), p. 219- 58.

Wilson, E. (1992). The Invisible Flâneur,New Left Review, V:191, p. 90-110. Retrieved fromhttp://www.newleftreview.org/?page=article \&view=1665

Wolff, J. (1994). The Artist and Flâneur: Rodin, Rilke and Gwen John in Paris, The Flâneur, (Ed. Keith Tester), London: Routledge, p.111-138. Retrieved fromhttp://books.google.com.tr/books?id=-OGPMUcnNvQC\&pg=PA1\&hl=tr\&source =gbs_toc_r\&cad $=4 \# \mathrm{v}=$ onepage $\& \mathrm{q} \& \mathrm{f}=\mathrm{false}$

Zarro, M. ; Hall, C. (2013). Wedding Dresses and Wanted Criminals: Pinterest.com as an Infrastructure for Repository Building, Seventh International AAAI Conference on Weblogs and Social Media, p.650-658.Retrieved from www.aaai.org 